\title{
Entrepreneurial Intention among Students to Venture into Entrepreneurship through Flea Market Retailing in Oman
}

\author{
Noor ALSHANFARI, Hasliza HASSAN, Melissa Wendy MIGIN \\ Faculty of Management, Multimedia University, Cyberjaya, Selangor, Malaysia,
}

\begin{abstract}
Entrepreneurship is a vital economic activity to support local communities. It is perceived as a significant avenue for influencing the youngsters to a start-up business. The growing number of graduates annually has become one of the main challenges for the Omani government. Therefore, entrepreneurship has become one of the essential measures for reducing the escalating unemployment rate due to the low national recruitment rate in the public and private sectors in Oman. This research aims to examine the extent of the entrepreneurial intention of youngsters, especially among 322 tertiary students from colleges of applied sciences in Oman, to venture into entrepreneurship through the flea market retailing by adopting the theory of planned behavior (TPB). The findings highlight the impact of education on entrepreneurial intentions, which will provide resources in the area of entrepreneurial education to online libraries for research students and also provides useful policy directions to the Oman government in its effort to actively promote entrepreneurship and business ventures through the Al Raffd Funds.
\end{abstract}

Key words: Entrepreneurship, Entrepreneurial education, Oman

\section{INTRODUCTION}

The Sultanate of Oman is relatively a small country covering 309500 landmass area square kilometers. It is an Arab country in the Middle East bordering the United Arab Emirates, Yemen, and the Kingdom of Saudi Arabia. Oman's population is approximately 3 million. As of April 23rd, 2016, Oman's population stood at 4,422,602, of which $2,412,919$ are Omanis. For that same year, the per capita income was $\$ 19,002$ (World Bank \& NCIS, 2016). The entrepreneurial spirit in Oman surged when the current Sultan Qaboos bin Said assumed power in 1970 and commenced a new era in the modern history of this country (Matriano \& Suguku, 2015). Despite various Oman government efforts to increase entrepreneurial awareness amongst the young, the participation rate is very slow. Most Omani graduates prefer to be employed in the public sector, and this cannot be sustainable as the number of university graduates is increasing every year (National Centre for Statistics and Information, 2018). This posed serious economic challenges that strained the capacity of education infrastructure and the job market. The two significant challenges hitherto are unemployment and lack of opportunities for higher education. These are the key reasons that compelled the government to provide measures for self-employment and entrepreneurial opportunities, especially for the young. Owing to the growing need for entrepreneurial establishments, this research tries to explore the importance of how entrepreneurship can be encouraged among the youngsters in Oman, primarily through entrepreneurial education.

\section{SIGNIFICANCE OF THE STUDY}

The study shall add to the stock of literature on the influence of entrepreneurial education on the intention of youngsters to venture into the flea market retailing in Oman. Theoretically, it will contribute to the understanding of youngsters' intentions toward flea market retailing, providing useful information for researchers and the general youth of Oman, especially given the looming unemployment crisis. This research also addresses the gap in the literature by extending the TPB (Ajzen, 1991) theoretical framework to include new construct: entrepreneurial education that can influence the entrepreneurial intention of youngsters with particular reference to the Omani Context. The study will provide relevant policy prescriptions on unemployment, entrepreneurship, youngsters, flea market and economic development to the 
Omani government whose primary goals over the recent decades have been to implement a learningbased economy, jobs creation and boost in the economic growth. Entrepreneurship gives individuals the opportunity to pursue their objectives, dreams and wants through business creation (Socorro \& Shah, 2015). Therefore, entrepreneurship has received increased attention in the country since the formation of new organizations can play essential roles as far as creating business, salary and new markets (Saeid et al., 2017). In fact, according to Ambad and Damit (2016), most economies have been looking for ways to utilize the capabilities of youngsters in developing new startups. Hence, entrepreneurship is said to be necessary for the future business climate of the community as it provides youngsters the opportunity for growth and a means by which they can achieve their potential (Hansson \& Brembeck, 2015).

\section{HISTORY OF FLEA MARKET IN OMAN}

A flea market in Oman has been around for decades, owing to the country's long history of artisanship and propensity for culture and oil mining in the country (Al-Lawati, 2017). It originated from Paris - France and has, after that the gained a substantial significance to Omani's social and economic platforms (Kumar, 2015). The history of the flea market in Oman dates back to the days of the Muttrah Souq market, situated in Muscat territory of Oman. This was before the revelation of oil when Muttrah was the focal point of trade in Oman. Today, Muttrah stands out as one of the largest seaports in this region owing to its history and development in commerce. Other features of commercial interest incorporate Souq Muttrah, the traditional bazaar as well as Sour Al-Lawatiah, a little network of walls that is encompassed by an old wall (Kumar, 2015). Flea markets in ancient Oman were characterized by canopied stalls, and streets were crowded.

Over the years, the flea markets in Oman have undergone adjustments to include emerging trends in these markets. The current flea market facility in Oman rents space to anyone that provides sale to the general public merchandise (Moritz, 2015; Obschonka et al., 2015). The main merchandise of the Omani flea market is household goods, shoes, and ready-made garments. Others include perfume, frankincense, fresh jasmine, and spices. On that hand, there are also small shops on street sides' alleyways that lead to the Souq selling Omani silver, embroidered kumahs, and white dishwashers, multicolored headscarves, and brightly coloured cloths. Ornamentals are also sold in these markets, including paintings, Omani pots, framed khan jars, hookah pipes, incense, and leatherwork (Kumar, 2015).

\section{THE SIGNIFICANCE OF FLEA MARKETS IN OMAN}

The flea market is significant for socio-economic development in Oman. The lack of entry barriers has encouraged societies to venture into entrepreneurship through flea market retailing as a platform (Nabi \&Kashif, 2016). The easy access to be involved in the flea market has expanded the scope of these markets, making them a significant source of revenue across Oman (Oman Economic Outlook, 2017). Entrepreneurs get started by renting commercial space in high niche areas that have a huge number of potential customers. Given the frequent number of individuals visiting the flea markets daily, these visitors can develop an understanding of entrepreneurship associated with this particular venue. Hence flea markets are critical hubs of social interactions, personal development, and economic opportunity (Fayolle \& Gailly, 2015). The price bargain between vendors and buyers has made significant contributions to the foundation of markets for many years. These range from peasant economies to flea markets and grand bazaars that shape the landscape of socio-economic dynamics (Al-Lawati, 2017). A common feature in Oman towns is the flea markets that serve the population with a variety of new and second-hand items, which are cheaper and therefore marketable. This avails the opportunity for the provision of commodities at competitive prices, which enhances competition (Al-Mahy, 2013).

\section{Government Support for Youth Entrepreneurship}

The present understudies are tomorrow's potential entrepreneurs, which may clarify why a growing number of colleges offer courses and projects in entrepreneurship (Al-Harthi,2017; Souitaris et al., 2007). The development of the entrepreneurship markets in Oman has been induced by the different working platforms such as semi-governmental institutions which offers the Ntilaaqah, Sas and Youth Partnership programs, as well as the influence from the government programs such as livelihood, Sanad and Rafad which encourage entrepreneurship among the Omani youth (Belwal et al., 2015).

Oman has taken three essential measures towards the development of entrepreneurship in the country. One of these measures is the provision of entrepreneurial education. The Sultanate has made considerable efforts in providing the necessary access to education that is geared towards fostering self-employment as well as providing a feasible 
option for job-seekers in Oman (Al-Ani, 2017). In order to transform education into practicality, the government has also increased access to funds for trained graduates. For instance, the SANAD program was initiated to target Omani young. The program grants loans to ambitious youths to venture into entrepreneurship. This is a proactive approach that offers towards encouraging entrepreneurship (Al-Harthi,2017).

The second measure for developing entrepreneurship in Oman is strengthening the ties between education and the industry. Educational institutions respond to the need of the economy by providing a suitably qualified and skilled workforce (Bae et al., 2014). For the practical realization of this measure, the Omani government is working towards developing strong and active ties between the various industries in order to identify the existing and potential gaps in the labor market. Understanding the gaps in the labor industry could yield various small-scale business ideas, and further research could be done on the viability of flea marketing in such areas. Overall, the quality and accessibility of entrepreneurship are vital in shaping the decisions of youngsters towards flea markets and also promoting economic growth and competitiveness in Oman (Petrescu \& Bhatli,2013).

The third measure is the facilitation of women entrepreneurship. In the history of most countries, women entrepreneurship has faced additional obstacles compared to their male counterparts. Therefore, practical initiatives are being taken to enhance equality in women's entrepreneurial development (Jennings \& Brush, 2013). The International Labor Organization pegged the unemployment rate at 7.17 percent in 2016. In contrast, currently, Oman has an $8.1 \%$ unemployment rate, which is the highest in the Gulf Cooperation Council (GCC) (World Bank, 2017). Hence all the measures discussed above will significantly contribute to bringing about job opportunities for Omani nationals. The country's effort to promote entrepreneurship as a career option goes a long way not only to solve the unemployment problems but also sustain the per capita income (AlLawati, 2017).

\section{The Importance of Young Entrepreneurship in Oman}

The present understudies are tomorrow's potential entrepreneurs, which may clarify why a growing number of colleges offer courses and projects in entrepreneurship (Al-Harthi,2017; Souitaris et al., 2007). Although Omani graduates have the right attitude towards entrepreneurship, they have a low inclination to begin their own business after graduation (Ibrahim, Devesh \& Ubaidullah, 2017). Given that they are young, the importance of nurturing cannot be overlooked. By increasing graduate's business knowledge and understanding of risks involved in the business as well as promoting entrepreneurship education can positively enhance the youths' attitude towards entrepreneurship. Therefore, educational institutions, private sectors, and the government have a collective role to play in changing the attitude of graduates towards coming up with practical entrepreneurship (Ibrahim et al., 2017). Previous studies show that investing in young people is approximately similar to investing in the future economy (Al Mamari, 2015; Al-Sadi, Belwal \& AlBadi, 2013; Dess \& Lumpkin, 2005; Dickinson,2013; Kautonen, Gelderen \& Tornikoski, 2013; Peterman \& Kennedy,2003; Souitaris, Zerbinati \& Al-Laham, 2007). The interest to focus on young entrepreneurs is based on the understanding that young people are the ones facing many unemployment problems (Al Mamari, 2015). Due to this, there is a need for the young to find solutions to their problems. The government is willing to provide the necessary support and the enabling environment for the young to avail opportunities (Adekiya \& Ibrahim, 2016). However, focusing on the young can be effectively successful when various entrepreneurship challenges affecting young in Oman are addressed.

\section{Entrepreneurial Education}

One of the factors that influence entrepreneurial intention is entrepreneurship education. The inclusion of entrepreneurial education as a construct investigates the impact of professional training on prospective entrepreneurs. Many researchers examined the effect of entrepreneurship education programs on entrepreneurial intentions and found significant positive effects (Audretsch et al.,2011; Borozan \& Pfeifer, 2014; Liñán et al.,2011). For the development of these intentions, the first independent construct is the entrepreneurial education, which is considered as the training and exposure to skills required in the actualization of the self-employment skills. In this case, the education can be formal or informal setups, given the context of the flea markets. Al-Lawati (2017) stated that one of the ways to promote the right attitude towards entrepreneurship is through entrepreneurial education. So, it can be said that the success of new start-ups partly relies upon the entrepreneur's knowledge on how to transform their ideas into businesses. This brings in the entrepreneurial development, which the research considers as the process of starting and developing the businesses. The role of education in developing the attitudes towards entrepreneurship forms the basis of these 
constructs, in addition to the subjective norms that the training dedicated to the subjects (Al-Balushi \& Anderson, 2017). Since the educational exposure brings some form of formalities in the approach towards the ventures that bring in the aspect of the perceived behavioral control, a factor that is relevant for this construct (Rauch \& Hulsink, 2015). Based on Bindah and Magd (2016), participation in entrepreneurship training programs was seen to have a positive effect on the desire to begin a new business. However, due to the constant evolution of the market, the skills involved in building an enterprise are mainly determined by the demand and supply opportunities of the current market (Okeke et al., 2016).

Moreover, even though flea markets have been around for many decades in Oman, the evolution of the market strategies has created a consistent flow of opportunities. This makes it vital for prospective entrepreneurs to acquire the necessary skills to not only identify the opportunities but also capitalize on their strengths. Therefore, this study evaluates the entrepreneurial training offered to students in the institutions of higher education in order to understand the influence of entrepreneurship education on the entrepreneurial intention of the Omani youth since the upcoming challenges and changes in marketing strategies demand for updated skills that can be acquired through entrepreneur courses (Shaykhutdinova et al., 2015).

\section{Prevalence of Entrepreneurship Education in Oman}

The Sultanate of Oman has expended much effort in promoting the level of entrepreneurship literacy in the country, to conform to the millennium development goals. The number of youngsters accessing training and advanced education is high, a factor that has encouraged the improvement of the professional skills across the sectors. On a global scale, the transformation of the educational approach to include skills and expertise has been influential in the current approach (Willaby et al., 2015). Due to the impact of technology, white-collar jobs have been deficient, considering the influx of candidates in the country. To some extent, the curriculums have changed in such a way that there is considerable focus on equipping skills that will help in self-employment (Henry \& Lewis, 2018). Most of the advanced courses consider skills that can help individuals to come up with new ideas. Such efforts have been instrumental in the rising numbers of entrepreneurs in the country, even though the highest percentages have been from the technical courses.

Entrepreneurship education is vital for the development of the relevant skills and competencies to start businesses (QAA, 2012 \& Mahieu, 2006). Unlike the other professional expositions, the training on entrepreneurship usually embarks on the empowerment if the subjects in such a way that they can understand the market and capitalize on the opportunities. Factors such as the risks on investment are important considerations in this case, due to the need for creating effective strategies. The aspect of identifying the demand and supply factors is part of the education since it enables the subjects to focus on what the market requires (Barringer \& Ireland, 2015). Since the venture deals with business principles, the education forums are essential platforms for the updating of the skills and competencies that will be favorable for the enterprises.

\section{Market Opportunities for the Young}

Abdel Karim (2017) stated that entrepreneurship had created great opportunities for individuals to achieve financial independence and benefit from the country's economic growth by generating entrepreneurial activities, making it an engine for the long-term growth of any economy. Oman is ranked the 17 thmost attractive place for retail investment destinations in the world (World Bank, 2017). This is among the 30 developing markets based on their robust economy, increasing consumer confidence, and growing population (Atef \& Al-Balushi, 2015). These are contributory factors that make Sultanate a preferred growth location for both global and regional players (Al-Mawali, Hasim \& Al-Busaidi, 2016). Based on the Global Retail Development Index (GRDI) 2014 report, Omani retail sales have grown by $7 \%$ since 2011 . There is a concentration of growth in retail sales that have originated from the flea markets. These are concentrated in Muscat, where nearly half the population lives. Despite its size, Oman has exhibited a stable economy as well as increased access to credit. On the other hand, the larger Gulf Cooperation Council (GCC) region has continued to show dynamic strength in the retail market. This makes the United Arab Emirates, Saudi Arabia, and Kuwait join Oman in the top 20 most attractive retail market hubs (Oxford Business Group, 2017).

Oman has had long-trade engagements with many nations, in the line of business exchanges and development of small-scale traders. These engagements have been useful in the creation of growth and development plans, targeting the business sector. The role of the international markets in providing opportunities for merchandise is very significant, with the flea markets enjoying the benefits of export and imports from the traders from Oman and other countries (Al-Mahy, 2013). This is not only on the local market but also in the 
international market for goods in transit from Asia to Egypt and other countries in the west that are accessible to the ocean for water transport. This makes Oman a suitable place for flea market based on the fact that old trade has fed Oman with treasure products and ancient ones that are of interest to various categories of people (Al-Lawati, 2017). The cultural factors and business approaches have been influential in making Oman a venture for foreign investors due to the positive factors from history.

Greene (2005) argued that flea markets provide opportunities to young entrepreneurs with little capital. For instance, some flea market-based startups may require less than US\$1,000 (RO 385 in the Omani market (Yarahmadi \& Magd, 2016). Flea markets also provide social benefits, which are significant for entrepreneurial development (Visconti et al. 2014). According to Olds (2009), a viable flea market is not only an economic engine but also a place for social gathering, which is significant for an entrepreneur to start up business (Petrescu \& Bhatli, 2013). Thus, flea markets often create a sense of community by bringing together a large number of buyers and sellers to a specific area. This assembly of different people can be beneficial for entrepreneurs as it allows them to develop stronger social relationships with the locality (Vogel, 2015). In the case of the youth, having such inter-generational and cross-racial interactions encourages the sharing of practical skills and knowledge. Furthermore, such social environments act as sources of ideas, which would help encourage the young population to engage in a retail flea market or create interest towards entrepreneurship (Yarahmadi \& Magd, 2016). According to Petrescu and Bhatli (2013), flea markets play the crucial role of a suitable springboard for the Omani youth wishing to venture into entrepreneurship, especially in the shadow of the economic retreat.

\section{Challenges of Young Entrepreneurship}

As per the National Centre for Statistics and Information (2018) reports that Oman produces, on average more than 15,000 graduates annually. Despite Oman's richness and business-friendly policies, the country is experiencing a high rate of unemployment, especially among the youth (World Bank, 2017). A large number of graduates produced annually remain jobless because of mismatch in skill sets. This has aggravated the unemployment and under-employment problems (Tran, 2016). With the Sultanate's unemployment rate on the rise, the country thought it crucial to take immediate initiatives to solve the problem (Ministry of Information \& Statistics, 2016). One of the avenues is to encourage youngsters to embrace entrepreneurship. All the government efforts towards tackling the unemployment situation have yielded minimal success (Al-Lawati, 2017). This is attributed largely to the low skill sets, unmotivated attitude and, lack of financial resources and interest among the graduates and youngsters towards jobs and business opportunities. Studies show that the Omani retail sector contributes only around $8 \%$ to its Gross Domestic Product (GDP). This is because of most of the youth view entrepreneurship as a transitory or temporary job (Fayolle \& Gailly,2015).

There is an extensive array of literature that has examined the changes in people's attitudes and expectations towards innovative entrepreneurial programs (Ajzen, 2011). Few empirical studies have examined the entrepreneurial propensity of university students as a source of future entrepreneurs (Liñán, Urbano \& Guerrero, 2011). However, there is little understanding of the contextual factors that affect students' intentions of becoming entrepreneurs and the relationship between such factors and students' entrepreneurial attitudes and intentions (Souitaris et al.,2007). Therefore, the primary objective of the study is to determine the impacts of entrepreneurial education on entrepreneurial intention among youngsters to venture into entrepreneurship through flea market retailing in Oman.

\section{CONCLUSIONS}

In summary, the purpose of this research proposal is to examine the entrepreneurial intentions of youngsters to venture into entrepreneurship in Oman. This research is cognizant of the fact that the developments of markets in the world economies are significant in attracting both social and economic interests. Given the current social and economic position of Oman, there seems to be a lot of potential in exploiting the flea markets as areas where the government can help the youngsters to find solutions to the impending problems of unemployment, introducing new product or service to the market, upgrading socio-economic lifestyle, providing varieties of product, supporting tourism industry, providing side income for part-timers and strengthening the economy, among others.

This research proposal is quantitative and exploratory, where the focus is on investigating the entrepreneurial intention of young people to venture into the flea market in Oman. A modified TPB model comprising seven variables with twenty-one corresponding hypotheses were developed. The research will be conducted in Oman with the target population of students in tertiary education. The sample is selected using stratified random sampling techniques, and based on Saunders et al. (2009), the actual final sample size needed will be 322 . There is hardly an in-depth study on the flea market and 
entrepreneurship in the Omani context. Therefore, there is a dire need for the present research to investigate the issues of entrepreneurship in a developing country like Oman.

\section{REFERENCES}

[1] Ng, M., Fleming, T., Robinson, M., Thomson, B., Graetz, N., Margono, C., ... \& Abraham, J.P. (2014). Global, Regional, and National Prevalence of Overweight and Obesity in Children and Adults During 1980-2013: A Systematic Analysis for the Global Burden of Disease Study 2013. The Lancet, Vol. 384, No. 9945, pp. 766-781.

[2] NHS Choices, (2016). What Should My Daily Intake of Calories Be?

[3] Lim, W. M. \& Ting, D. H. (2011). The Construction of Beauty in Malay Magazine Advertisements. Contemporary Management Research, Vol. 7, No. 3, pp. 173-196.

[4] Clark, K. (2013). Picture perfect: How Editors of Women's Magazines Depict Fitness. What Messages Do Editors Send through Cover Sell Lines and Images?.

[5] Thamby, S. A., Sheng, C. C. \& Yau, K. W. (2013). Assessment of Patients' Perceptions about Modalities of Treatment in some Obesity Clinics (Slimming Centers) in the State of Kedah, Malaysia. Innovations in Pharmaceuticals and Pharmacotherapy.

[6] Tan, Y. L. (2014). US Magazine: Malaysia's Healthcare is No. 3 Worldwide, The Star Online.

[7] Hockton, K. (2017). Malaysia: Medical Tourism is Booming, 4 Countries with the Best Healthcare in the World 2017, International Living, pp. 1-12.

[8] Jenkins, N. (2011). Massage for Weight Loss. Natural Therapy Pages.

[9] Wong, C. (2017). Deep Tissue Massage Explained: Benefits and Tips to Get the Most Out of One, Holistic Health, Verywell.

[10] DeBusk, C. (2015). 4 Benefits of A Deep Tissue Massage, Massage Magazine.

[11] Hexsel, D., \& Mazzuco, R. (2013). Cellulite. In Update in Cosmetic Dermatology, pp. 21-32.

[12] Tadlock, L. (2013). Can Massage Promote Weight Loss? LiveStrong.com

[13] Stellner, A. (2013). Electrotherapy for Weight Loss. LiveStrong.com

[14] Amula, D. (2016). Weight Loss Using Electronic Muscle Stimulation (EMS), DietWeight Management, Weight Loss, Bellissimo.
[15] Cressy, S. (2004). Beauty Therapy Fact File. Heinemann.

[16] Greenfield, B. (2015). Can You Lose Fat with Electical Muscle Stimulation (EMS)? QuickAndDirtyTips.com

[17] My Microcurrent Health (2017). Facial Farradic \& EMS: Electrical Muscle Stimulation, Facial Faradic.

[18] Seward, M. (2015). Far Infrared Saunas for Weight Loss, Healthy Focus.

[19] Petros, R. (2015). Do Infrared Saunas Work to Lose Weight?, LiveStrong.com

[20] Moore, S. (2012). Infrared Saunas \& Weight Loss, The Ultimate Weight Loss Solution - Far Infrared Saunas, EvolutionHealth.com

[21] Myers, A. (2014). 6 Benefit of Infrared Sauna Therapy.

[22] Biro, S., Masuda, A., Kihara, T., \& Tei, C. (2003). Clinical Implications of Thermal Therapy in Lifestyle-Related Diseases. Experimental Biology and Medicine, Vol. 228, No. 10, pp. 1245-1249.

[23] Innovative Body \& Skin Rejuvenating Solutions (2017). Thermal Detox Slimming Blanket.

[24] The Loop Celebrating Community (2015). Far Infrared Sauna Blanket Health Benefits.

[25] Geliebter, A., Krawitz, E., Ungredda, T., Peresechenski, E., \& Giese, S. Y. (2015). Physiological and Psychological Changes Following Liposuction of Large Volumes of Fat in Overweight and Obese Women. Journal of Diabetes and Obesity, Vol. 2, No. 4, pp. 1-7.

[26] Walansky, A. (2014). Body Slimming Products and Treatments: What Actually Works.

[27] Hong, Y. G., Sim, H. B., Lee, M. Y., Seo, S. W., Chang, C. H., Yeo, K. K., \& Kim, J. K. (2012). Three-Dimensional Circumferential Liposuction of the Overweight or Obese Upper Arm. Aesthetic Plastic Surgery, Vol. 36, No. 3, pp. 497-503.

[28] Berry, M. G. (2016). The Principles and Techniques of Liposuction. In Liposuction, pp. 149-160.

[29] Hernández-Pérez, E., Seijo-Cortes, J. A., \& Khawaja, H. A. (2016). Large-Volume Liposuction for Obesity. In Liposuction, pp. 225237.

[30] Seretis, K. (2016). Weight Reduction Following Liposuction. In Aesthetic Plastic Surgery of the Abdomen, pp. 387-395. 
Noor, Hasliza \& Melissa / International Journal of Business and Management, 6(1) 2022, Pages: 12-17

[31] Gargulinski, R. (2015). Cold Laser for Weight Loss, LiveStrong.com

[32] Andersen, C. H. (2017). I Tried It! Laser Fat Removal, Does Laser Lipo Work? One Writer Tried the New Zerona Laser To See If It Lives Up To Its Claims.

[33] Mann, D. (2010). Debate on Laser Liposuction to Remove Fat. Study Show Technique Remove Fat and Helps Skin Tightening; Critics Worry About Burns.
[34] Green, S. B. (1991). How Many Subjects Does It Take To Do A Regression Analysis? Multivariate Behavioral Research, Vol. 26, pp. 499-501.

[35] Enders, C. K. (2003). Using the Expectation Maximization Algorithm to Estimate Coefficient Alpha for Scales with Item-Level Missing Data. Psychological Methods, Vol. 8, No. 3, pp. 322-337. 